\title{
Increased deposition of C3b on red cells with low CRI and CD55 in a malaria-endemic region of western Kenya: Implications for the development of severe anemia Collins O Odhiambo1, Walter Otieno ${ }^{1}$, Christine Adhiambo ${ }^{1}$, Michael M Odera ${ }^{1}$ and José A Stoute ${ }^{* 2,3,4}$
}

Address: ${ }^{1}$ The US Army Medical Research Unit and the Kenya Medical Research Institute, Nairobi, Kenya, ${ }^{2}$ Department of Medicine, the Uniformed Services University of the Health Sciences, Bethesda, Maryland, USA, ${ }^{3}$ Division of Malaria Vaccine Development, Department of Cellular Injury, The Walter Reed Army Institute of Research, Robert Grant Avenue, Silver Spring, MD 20910, USA and ${ }^{4}$ Pennsylvania State College of Medicine, 500 University Drive, MC: H036, Rm C6833, Hershey, PA 17033, USA

Email: Collins O Odhiambo - codhiambo@wrp-ksm.org; Walter Otieno - wotieno@wrp-ksm.org; Christine Adhiambo - cadhiambo@wrpksm.org; Michael M Odera - modera@wrp-ksm.org; José A Stoute* - jstoute@psu.edu

* Corresponding author

Published: 2I August 2008

BMC Medicine 2008, 6:23 doi:10.1 I86/174|-70/5-6-23
Received: 26 November 2007

Accepted: 21 August 2008

This article is available from: http://www.biomedcentral.com/174I-7015/6/23

(c) 2008 Odhiambo et al; licensee BioMed Central Ltd.

This is an Open Access article distributed under the terms of the Creative Commons Attribution License (http://creativecommons.org/licenses/by/2.0), which permits unrestricted use, distribution, and reproduction in any medium, provided the original work is properly cited.

\begin{abstract}
Background: Severe anemia due to Plasmodium falciparum malaria is a major cause of mortality among young children in western Kenya. The factors that lead to the age-specific incidence of this anemia are unknown. Previous studies have shown an age-related expression of red cell complement regulatory proteins, which protect erythrocytes from autologous complement attack and destruction. Our primary objective was to determine whether in a malaria-endemic area red cells with low levels of complement regulatory proteins are at increased risk for complement (C3b) deposition in vivo. Secondarily, we studied the relationship between red cell complement regulatory protein levels and hemoglobin levels.
\end{abstract}

Methods: Three hundred and forty-two life-long residents of a malaria-holoendemic region of western Kenya were enrolled in a cross-sectional study and stratified by age. We measured red cell C3b, CRI, CD55, and immune complex binding capacity by flow cytometry. Individuals who were positive for malaria were treated and blood was collected when they were free of parasitemia. Analysis of variance was used to identify independent variables associated with the \%C3bpositive red cells and the hemoglobin level.

Results: Individuals between the ages of 6 and 36 months had the lowest red cell CRI, highest \%C3b-positive red cells, and highest parasite density. Malaria prevalence also reached its peak within this age group. Among children $\leq 24$ months of age the \%C3b-positive red cells was usually higher in individuals who were treated for malaria than in uninfected individuals with similarly low red cell CRI and CD55. The variables that most strongly influenced the \%C3b-positive red cells were age, malaria status, and red cell CD55 level. Although it did not reach statistical significance, red cell CRI was more important than red cell CD55 among individuals treated for malaria. The variables that most strongly influenced the hemoglobin level were age, the \%C3b-positive red cells, red cell CRI, and red cell CD55.

Conclusion: Increasing malaria prevalence among children $>6$ to $\leq 36$ months of age in western Kenya, together with low red cell CRI and CD55 levels, results in increased C3b deposition on red cells and low hemoglobin. The strong contribution of age to $\mathrm{C} 3 \mathrm{~b}$ deposition suggests that there are still additional unidentified age-related factors that increase the susceptibility of red cells to C3b deposition and destruction. 


\section{Background}

Plasmodium falciparum malaria is responsible for 1 to 2 million deaths per year, with most in sub-Saharan Africa [1]. One unexplained but consistent feature of the epidemiology of clinical malaria is the age distribution of syndromes of severe disease. Severe anemia is most common in areas of intense transmission of $P$. falciparum and tends to occur in children $<3$ years of age, whereas cerebral malaria occurs in areas where the annual inoculation rate is low, and it occurs in older children and adults [2-5].

The pathogenesis of severe anemia in malaria is complex. However, a number of observations suggest that the destruction of uninfected red cells is a significant contributor to, if not the major cause of, this anemia: uninfected red cells have a decreased life span in patients with $P$. falciparum [6] and the hematocrit can continue to decrease for days following treatment [7]. Further, the fact that the life span of erythrocytes is 120 days suggests that bone marrow dysfunction would have to be very prolonged to make a significant contribution to this anemia. A mathematical model of severe malarial anemia has revealed that with each lysed infected erythrocyte a further 8.5 uninfected erythrocytes are destroyed [8]. These observations suggest that destruction of uninfected red cells takes place during malaria infection. Complement activation and its deposition on red cells are prime suspects in this process. Complement is activated during malaria infection $[9,10]$ and $\mathrm{C} 3 \mathrm{~d}$ and $\mathrm{IgG}$, molecules that are implicated in the removal of senescent red cells via erythrophagocytosis [11], have been detected on red cells of children with severe malaria $[12,13]$.

In order to understand the nature of the susceptibility of red cells to complement activation during malaria infection we have investigated the expression of red cell complement regulatory proteins in persons living in a malariaendemic area. Complement receptor 1 (CR1, CD35) is a $200 \mathrm{kDa}$ protein that is found on red cells and most leukocytes [14]. It also accelerates the decay of C3 and C5 convertases, protein complexes that catalyze the cleavage of $\mathrm{C} 3$ and $\mathrm{C} 5$ into $\mathrm{C} 3 \mathrm{~b}$ and $\mathrm{C} 5 \mathrm{~b}$ respectively [15]. Red cells are able to bind C3b-bearing immune complexes (ICs) via CR1 and carry them to the liver and spleen where they are removed from circulation $[16,17]$. Therefore, CR1 prevents the deposition of $\mathrm{C} 3 \mathrm{~b}$ on cell surfaces and has a critical role in the removal of ICs from circulation.

The other red cell complement regulatory protein that we have studied is decay accelerating factor (DAF, CD55) [18]. It is a $70 \mathrm{kDa}$ protein linked to the cell membrane via glycosyl-phosphatidyl-inositol (GPI). CD55 catalyzes the degradation of $\mathrm{C} 3$ convertases and also promotes the inactivation of C3b $[19,20]$. Deficiency in membrane DAF and CD59, a third red cell complement regulator, leads to paroxysmal nocturnal hemoglobinuria, a condition char- acterized by massive hemolysis due to complement activation on red cells. Consequently, red cell complement regulatory proteins may play an important role in protecting red cells from complement-mediated destruction as a result of IC formation and complement activation that occur during malaria infection $[9,21]$. Consistent with this hypothesis, we have found that red cells of children with $P$. falciparum infection and severe anemia have acquired deficiencies in CR1 and CD55, and increased C3b deposition $[13,22]$. Excessive C3b deposition on red cells during malaria infection as a result of deficiency in red cell complement regulatory proteins may result in increased destruction of red cells by phagocytosis and severe anemia [15].

To understand the age predilection of severe anemia during $P$. falciparum infection, we have studied the relationship between red cell CR1 and CD55 and age. Our studies suggest that the expression of red cell CR1 and CD55 are age-dependent, decreasing from birth to a nadir somewhere between 1 and 2 years of age and rising thereafter [23]. This pattern has been observed in populations of diverse ethnic origin and is independent of malaria infection. We have proposed that the changes in the expression of red cell complement regulatory proteins with age may influence the susceptibility of red cells to complementmediated damage and, by extension, the age predilection for severe anemia during malaria infection [24]. To test whether the susceptibility of red cells to C3b deposition is influenced by the age-related changes in complement regulatory proteins we carried out a cross-sectional study of individuals in a malaria-holoendemic region of western Kenya, measured their red cell CR1, CD55, and IC binding capacity, and determined the \%C3b-positive red cells.

\section{Methods \\ Study design and population}

The study was cross-sectional in design and was approved by the Walter Reed Army Institute of Research Human Use Research Committee and by the National Ethical Review Committee, Nairobi, Kenya. It was carried out from October through December 2004 in Kombewa Division, an area off the shores of Lake Victoria within Kisumu District. Malaria is holoendemic in this region, occurring throughout the year with peak seasons during the long rains (March through August) and during the short rains (October through December) [25]. The area is divided into four sub-Divisions and 12 political locations with approximately 62,000 inhabitants. The majority of the inhabitants are of the Luo ethnic group and dedicate themselves to subsistence farming and fishing.

Enrollment was stratified into nine age groups selected based on the age distribution of children with severe anemia $(\mathrm{Hgb} \leq 5.0 \mathrm{~g} / \mathrm{dl})$ and $P$. falciparum malaria from Kisumu District, western Kenya, who participated in our 
studies from 1998 to 2001 [13,26,27]: 0 to $\leq 6$ months, $>6$ to $\leq 12$ months, $>12$ to $\leq 18$ months, $>18$ to $\leq 24$ months, $>24$ to $\leq 36$ months, $>36$ to $\leq 72$ months, $>72$ to $\leq 144$ months, $>144$ to $\leq 288$ months, and $>288$ to $\leq 540$ months. Since we had no previous data on the levels of C3b deposition on red cells, enrollment targets for each group were set to maximize the probability of detecting significant differences between the $>6$ to $\leq 12$ month group, where we had seen the lowest level of CR1 in a previous study [28], and other groups. The inclusion criterion was any person male or female of age 45 years or younger who was a life-long resident of the study area. As many conditions including malaria [13], HIV infection [29], and others $[30,31]$ can alter the level of red cell complement regulatory proteins, the following exclusion criteria were established: 1) evidence on clinical grounds of malnutrition manifested by marasmus or kwashiorkor; 2) immunocompromised status manifested by weight loss, thrush, or diffuse adenopathy; 3 ) severe anemia (Hgb $\leq$ $5.0 \mathrm{~g} / \mathrm{dl}$ ); 4) bacterial infection (for example, pneumonia); 5) malignancy; and 6) blood transfusion within 3 months preceding the study.

A preliminary census was carried out within selected villages to identify potential participants. All individuals who met the entry criteria were invited to participate. On the days of recruitment individuals or parents with children self-reported to the clinic for enrollment in the study. Informed consent was obtained prior to any procedures. Individuals underwent a standard medical evaluation. Date of birth was confirmed by national registration card, baptismal certificate, or birth certificate. During the initial screening, blood obtained by finger prick was used to prepare thick and thin Giemsa-stained blood smears. If an individual was positive for malaria, he or she was treated with artemether/lumefantrine [32] and asked to return 2 weeks later for re-evaluation. Individuals who were febrile (oral or axillary temperature $>37.5^{\circ} \mathrm{C}$ ) without malaria were evaluated and treated for any minor illness identified and asked to return 2 weeks later. Individuals who returned for re-evaluation were screened for malaria again. If found to be malaria positive or febrile at this second screen, they were again evaluated, treated, and asked to come back 2 weeks later.

\section{Blood samples and smears}

Malaria smears were read by trained and certified microscopists. All smears were read in duplicate by independent microscopists who were unaware of the status of the participants. Discrepancies were settled by a third independent microscopist. A smear required a minimum of 200 high power fields scanned prior to being considered negative. Once an individual was deemed well and asymptomatic, a $2.5 \mathrm{ml}$ ethylenediaminetetraacetic acid (EDTA)anticoagulated sample of venous blood was obtained. An aliquot was used for complete blood count determination using an automated hematology analyzer (Coulter, Hialeah, FL). The remaining sample was centrifuged and the plasma removed. The red blood cell pellet was then cryopreserved until used [33].

\section{Flow cytometric measurement of CRI and CD55}

Erythrocyte CR1 and CD55 levels were determined using frozen samples. In preliminary experiments, we observed no difference in the level of red cell complement regulatory proteins between fresh and frozen samples. All primary antibodies were titered to saturation. $10 \mu \mathrm{l}$ of thawed erythrocyte pellet was washed twice in $1 \mathrm{ml}$ of Alsever's buffer and resuspended in the same volume of buffer. Unless otherwise stated, all procedures were as previously described [34]. The following primary antibodies were used in dilutions of 1:20: anti-CR1 clone E11, antiCD55 clone IA10, and isotype controls for each (BectonDickinson, Belgium). A secondary fluorescein isothiocyanate (FITC)-conjugated goat anti-mouse IgG (BectonDickinson, San Diego, CA) was used at a dilution of 1:50.

Flow cytometry was carried out using a FACScan flow cytometer (Becton-Dickinson). Analysis was done using FCS Express v2.5 (De Novo Software, Los Angeles, CA). Red cells were gated on the basis of their forward and side scatter characteristics using logarithmic amplification. The median fluorescence intensity (MFI) of each sample was measured using logarithmic amplification. The MFI values for CR1 and CD55 were normalized to the mean of the MFI of the red cell standard using the formula

$$
\text { CorrMFIs }=\text { MFIs } \times \text { MFIcmean } / \text { MFIc, }
$$

where 'CorrMFIs' and 'MFIs' are the corrected and uncorrected sample MFI respectively, 'MFIcmean' is the mean of all the MFI values of the standard control, and 'MFIc' is the mean of the control obtained in parallel with the sample. The number of molecules of CR1 per red cell was derived from a fluorescence standard curve created using cells with known CR1 numbers. Red cell anti-CD55 antibody binding capacities were derived from a standard curve created using beads of known antibody binding capacity (Bangs Lab, Fishers, IN) [35].

\section{Preparation of ICs}

$50 \mu \mathrm{l}$ of $49 \mathrm{mg} / \mathrm{ml}$ rabbit anti-BSA (Sigma-Adrich, St. Louis, MO) and $3 \mu \mathrm{l}$ of $5 \mathrm{mg} / \mathrm{ml}$ BSA-FITC (Accurate Chemical and Scientific Corp., Westbury, NY) were added to $950 \mu \mathrm{l}$ of RPMI1640 (Sigma-Aldrich). This combination was noted to be the point of equivalence in preliminary experiments. The mixture was incubated at $37^{\circ} \mathrm{C}$ for $1 \mathrm{hr}$ and overnight at $4^{\circ} \mathrm{C}$. The next day, the IC preparation of soluble and insoluble IC was aliquoted and stored at $-20^{\circ} \mathrm{C}$. 


\section{Measurement of $\mathrm{C} 3 \mathrm{~b}$ on red cells}

All centrifugation steps were at $\times 500 \mathrm{~g}$ for $5 \mathrm{~min}$. Rabbit polyclonal anti-C3a (negative control antibody) and antiC3b (Accurate) were pre-adsorbed $\times 3$ by adding a 1:50 dilution of antibody in phosphate buffered saline (PBS) pH 7.4 to an equal volume of packed pre-washed erythrocytes from the normal standard control. The cells were incubated for $1 \mathrm{hr}$ at $37^{\circ} \mathrm{C}$ with constant rocking followed by centrifugation. The pre-adsorbed antibody was frozen at $-20^{\circ} \mathrm{C}$ in single-use aliquots. $100 \mu$ of pre-washed freshly thawed erythrocytes at 1\% hematocrit in Alsever's buffer was added to wells of a 96-well plate and resuspended in $50 \mu \mathrm{l}$ of pre-adsorbed rabbit anti-C3b, antiC3a, or in PBS (unstained control), and incubated for 10 min at $37^{\circ} \mathrm{C}$. After two washes in PBS, the cells were resuspended in 1:50 anti-rabbit PE (Sigma-Aldrich) for $30 \mathrm{~min}$ at room temperature, washed twice, and resuspended again in PBS. Acquisition was carried out as above. The $\% \mathrm{C} 3 \mathrm{~b}$-positive cells were calculated by Overton subtraction [36] of the baseline C3a histogram from the baseline C3b histogram.

\section{Measurement of IC binding capacity}

For IC opsonization, $5 \mu \mathrm{l}$ of stock IC or RPMI 1640 (unstained control) was incubated in a total volume of $100 \mu \mathrm{l}$ containing $30 \% \mathrm{AB}+$ serum in wells of a 96-well plate. For a negative control, a separate set of wells contained IC plus $10 \mathrm{mM}$ EDTA. Following incubation at $37^{\circ} \mathrm{C}$ for $30 \mathrm{~min}$ with constant rocking motion, $100 \mu \mathrm{l}$ of $1 \%$ hematocrit suspension of freshly thawed red cells from each study participant or from a standard aparasitemic control in RPMI 1640 was added to each of the wells of the above 96-well plate. This was followed by further incubation for $30 \mathrm{~min}$ at $37^{\circ} \mathrm{C}$. The erythrocytes were then washed twice in $200 \mu \mathrm{l}$ of ice-cold RPMI 1640, resuspended in PBS containing 1\% paraformaldehyde, and stored at $4^{\circ} \mathrm{C}$ until acquisition. After gating, the erythrocyte FITC fluorescence was measured using logarithmic amplification and the positive cutoff was set using the unstained cells. The percent of positive red cells (IC binding capacity) was calculated based on this cutoff. To control for day-to-day variation, the IC binding capacity was normalized to the mean IC binding capacity of the red cell standard used throughout using a formula similar to the one used for correction of CR1 and CD55 (above).

\section{Statistical analysis}

Statistical analysis was carried out using SPSS v11.5 (SPSS Inc., Chicago, IL). The flow cytometry and parasite density data are presented graphically for each age group as box plots, where the box represents the boundaries between the $25^{\text {th }}$ and $75^{\text {th }}$ percentile, the line through the box represents the median, the whiskers the $10^{\text {th }}$ and $90^{\text {th }}$ percentile limits, and the dots are the outliers. Analysis of variance (ANOVA) was used to detect differences across age groups adjusting for factors and covariates as indicated in the figure legends. P values were adjusted for multiple comparisons using the Sidak correction. The independent samples $t$-test was used for comparisons of normal continuous data between two groups. The chisquare test was used to compare proportions across groups. The general linear model procedure was used to carry out univariate ANOVA and analysis of covariance (ANCOVA) to identify independent variables associated with the \%C3b-positive red cells and the hemoglobin level. Age groups, red cell CR1, red cell CD55, parasite density, malaria status, and IC binding capacity were the independent predictor variables included in the models. $\% \mathrm{C} 3 \mathrm{~b}$-positive red cells were also used as an independent variable for the hemoglobin level. Categorical variables were transformed into dummy variables and the B coefficient for the last group set to ' 0 ' for reference. All tests were two-sided with $\alpha \leq 0.05$.

\section{Results \\ Demographic and clinical characteristics of the study population}

Four hundred and two potential participants or parents of children who met the inclusion criterion signed the consent form and were screened. Of these, 344 met none of the exclusion criteria, attended the screening sessions, and agreed to provide blood samples (Table 1). Blood samples could not be drawn in sufficient quantities from two individuals, making the final number of samples available for the study 342. All individuals who were parasitemic were treated for malaria and in most cases the blood sample was collected 2 weeks later. Table 2 summarizes the demographic characteristics of the enrolled participants that contributed samples. We observed no difference in the proportion of locations or villages represented across the groups (data not shown).

\section{Red cell CRI, CD55, and IC binding capacity}

The nadir of hemoglobin level occurred in the $>12$ to $\leq 18$ month group (Figure 1a). For multiple comparison testing we collapsed the age groups for age $>6$ to $\leq 36$ months, which seemed to form a homogeneous subset in most analyses (data not shown), to reduce the number of comparisons and compared all other groups to this new group (Figure 1). The changes in hemoglobin level across groups were highly statistically significant. Although overall unadjusted changes in CR1, CD55, and IC binding capacity across age groups were statistically significant, only a limited number of comparisons were statistically significant after adjustment for malaria status and parasite density (Figure 1). Nonetheless, these findings confirm our previous results [37]. In the present study, children of between 6 and 36 months of age had the lowest red cell CR1 (Figure 1b) whereas children between 24 and 36 months of age had the lowest red cell CD55 (Figure 1c). 
Table I: Disposition of participants

\begin{tabular}{|c|c|c|c|c|c|}
\hline & \multirow[t]{2}{*}{ Enrolled $(N)$} & \multicolumn{2}{|r|}{ Deferred to Next Screen } & \multicolumn{2}{|r|}{ Excluded } \\
\hline & & $N$ & Reason for Deferral & $N$ & Reason for Exclusion \\
\hline Screen I & 190 & 194 & $\begin{array}{l}\text { 190- positive blood smear, } \\
\text { 4- non-malaria fever }\end{array}$ & 18 & $\begin{array}{c}\text { 3- refused blood draw } \\
\text { 12- malnourished or immunocompromised } \\
\text { 2- pneumonia } \\
\text { I- severe anemia }\end{array}$ \\
\hline Screen 2 & $15 \mid$ & 10 & All positive smear & 33 & $\begin{array}{l}\text { I- age cohort full } \\
32-\text { no shows }\end{array}$ \\
\hline Screen 3 & 3 & 0 & & 7 & $\begin{array}{l}\text { 4- no shows, } \\
\text { 3- age cohort full }\end{array}$ \\
\hline
\end{tabular}

Total

$344^{*}$

58

*Two individuals excluded due to insufficient sample.

The red cell IC binding capacity showed a pattern similar to that of CR1 but with a less marked rise in adulthood (Figure 1d).

\section{Red cell C3b, malaria prevalence, and parasite density}

The \%C3b-positive red cells increased from birth, peaked between 12 and 24 months of age and then decreased into adulthood (Figure 2a). Significant statistical differences in $\% \mathrm{C} 3 \mathrm{~b}$-positive red cells were observed when comparing children $>6$ to $\leq 36$ months with other age groups (Figure 1a). The prevalence of $P$. falciparum malaria and the parasite density both rose and peaked within this age group. However, the prevalence of $P$. falciparum malaria (Figure 2b) and the distribution of parasite densities among malaria-positive (heretofore referred to as malariatreated) individuals (Figure $2 \mathrm{c}$ ) were discordant. The parasite prevalence increased from birth to 18 months, and peaked between 18 and 24 months, remaining high up to age 12 years, and decreasing thereafter (Figure 2b). A similar age distribution of parasite prevalence was observed when all the individuals screened were included, except that the prevalence was higher across all groups (data not shown). On the other hand, the parasite densities among malaria-treated individuals peaked between 12 and 18 months of age and were highest between 6 and 36 months (Figure 2c).

When participants were subcategorized according to the presence or absence of $P$. falciparum at enrollment (Figure 3 ) we observed that there was an age-dependent distribution of \%C3b-positive red cells both in malaria-treated and aparasitemic individuals that was more marked in the former (Figure 3a). In addition, malaria-treated children of age $\leq 24$ months had a greater proportion of C3b-positive red cells than their aparasitemic counterparts, although the difference did not reach statistical significance in the $>12$ to $\leq 18$ month group. It was surprising to see that malaria-treated children of age $\leq 6$ months $(n=6)$ had a high level of \%C3b-positive red cells, but this was explained by relatively low red cell CR1 in these individuals. With few exceptions there were no significant differences in levels of CR1, CD55, and hemoglobin between malaria-treated and aparasitemic volunteers (Figures $3 \mathrm{~b}$ to $3 \mathrm{~d}$ ).

\section{Analysis of variance to detect associations}

We carried out analysis of variance to identify the factors most strongly associated with the \%C3b-positive red cells

Table 2: Population demographics

\begin{tabular}{cccc}
\hline Age Groups (Months) & Total $\mathbf{N}$ & No. Female (\%) & Median Age in Months (Range) \\
\hline 0 to $\leq 6$ & 30 & $17(56.7)$ & $2.6(0.4$ to 0.6$)$ \\
$>6$ to $\leq 12$ & 60 & $29(48.3)$ & $10.9(6.1$ to 12.0$)$ \\
$>12$ to $\leq 18$ & 34 & $13(38.2)$ & $14.2(12.1$ to 17.5$)$ \\
$>18$ to $\leq 24$ & 27 & $14(51.9)$ & $21.3(18.3$ to 23.7$)$ \\
$>24$ to $\leq 36$ & 31 & $14(45.2)$ & $28.6(24.2$ to 36.0$)$ \\
$>36$ to $\leq 72$ & 42 & $22(52.4)$ & $42.7(36.8$ to 70.5$)$ \\
$>72$ to $\leq 144$ & 39 & $17(43.6)$ & $99.2(73.1$ to 143.9$)$ \\
$>144$ to $\leq 288$ & 24 & $31(56.4)$ & $398.9(145.1$ to 288.0$)$ \\
$>288$ to $\leq 540$ & 55 & $169(49.4)$ & 290.7 to 540.0$)$ \\
\hline Total & 342 & & $29.7(0.4$ to 540.0$)$
\end{tabular}


a

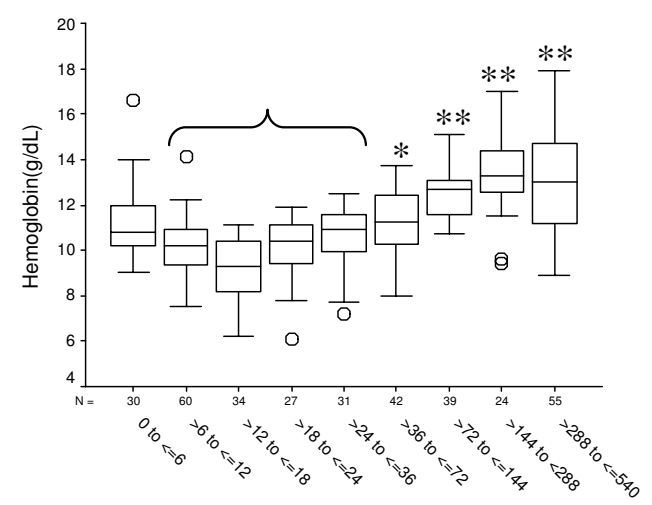

Age Groups(Months)

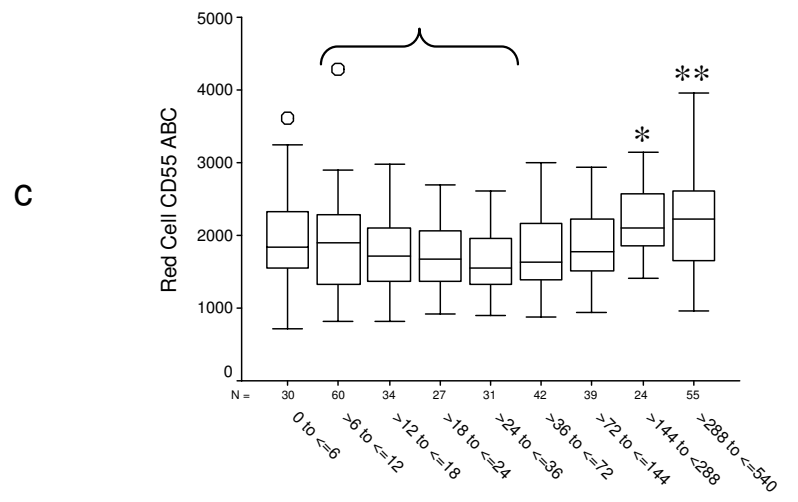

Age Groups(Months)

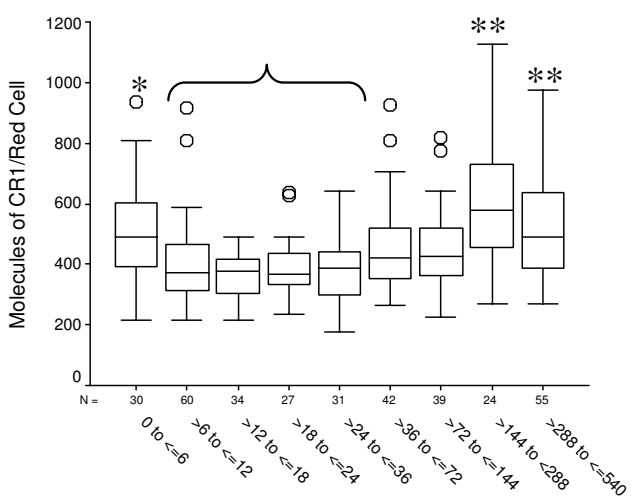

Age Groups(Months)

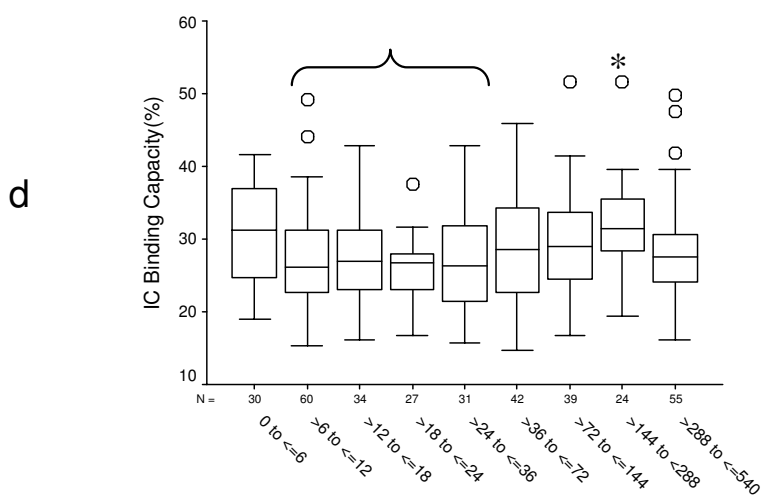

Age Groups(Months)

\section{Figure I}

Age-related changes in hemoglobin concentration, red cell CRI, CD55, and IC binding capacity. For multiple comparison testing all groups were compared with the group formed by collapsing the groups ranging in age from $>6$ to $\leq 36$ months (bracket). $P$ values were adjusted using the Sidak correction for multiple comparisons. $*=0.01<P \leq 0.05$, $* *=P<0.0$ I. a. Hemoglobin level. Unadjusted ANOVA for differences across groups $P=9.6 \times 10^{-38}$. After adjustment for red cell CRI, red cell CD55, \%C3b-positive red cells, malaria status, and parasite density, significant differences were found as indicated. b. Red cell CRI. Unadjusted ANOVA for differences across groups $P=1.5 \times 10^{-10}$. After adjustment for malaria status and parasite density differences were found as indicated. $c$. Red cell CD55. Unadjusted ANOVA for differences across groups $P=6$.I $\times 10$ 6. After adjustment for malaria status and parasite density significant differences were found as indicated. $A B C=A n t i b o d y$ binding capacity. $d$. binding capacity. Unadjusted ANOVA for differences across groups $P=0.004$. After adjustment for malaria status and parasite density significant differences were found as indicated.

and with the hemoglobin level in all the samples and in the subgroups of aparasitemic and malaria-treated participants (Tables 3 and 4). For the C3b analysis, terms for age groups, red cell CR1, IC binding capacity, malaria status (included for all the samples only), parasite density at enrollment, and red cell CD55 were used as independent variables. There were no significant interactions between CR1 and CD55, between CR1 or CD55 and age, or parasite density and other factors. The unadjusted and adjusted (all variables entered) results are presented in Table 3. Age was the most influential factor in all the anal- yses. Inclusion in the age group $>6$ to $\leq 36$ months always had the strongest positive effect on C3b deposition, as seen from its larger correlation coefficient and positive $B$ coefficient. In the unadjusted analysis, CR1 and CD55 were more influential than malaria status, parasite density, or IC binding capacity both in the global and in the subgroup analyses. After adjustment for all the confounding effects, malaria status and CD55 made the most significant contribution after age when all the samples were included, while CR1 showed a trend towards significance $(P=0.07)$. For the adjusted analysis of samples from 
a

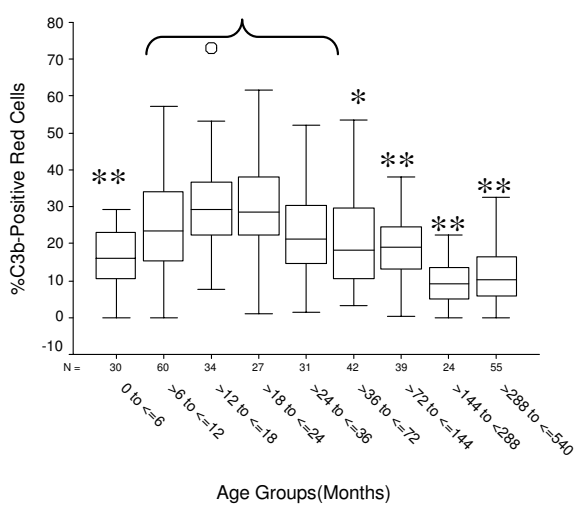

b

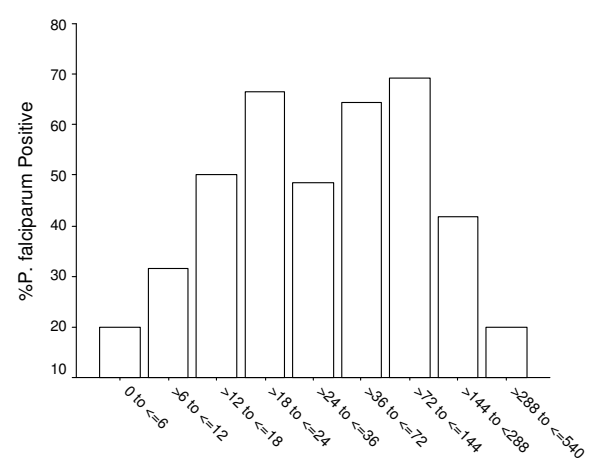

Age Groups(Months)

C

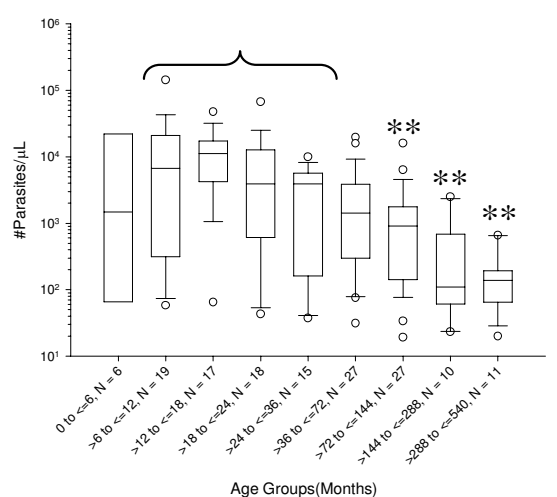

\section{Figure 2}

Changes in \%C3b-positive red cells, parasite prevalence, and parasite density with age. a.\%C3b-positive red cells by age. For multiple comparison testing age groups $>6$ to $\leq 36$ months were collapsed into one. $P$ values were obtained by oneway analysis of variance adjusting for red cell CRI, red cell CD55, IC binding capacity, malaria status, and parasite density. ${ }^{*}=$ $0.0 \mathrm{I}<P \leq 0.05$, $* *=P<0.0$ I. Sidak correction for multiple comparisons was used. b. Prevalence of parasitemia by age group. c. Parasite density among malaria-positive individuals by age group. Parasite densities were Log $_{10}$-transformed due to unequal variances between groups. Groups from $>6$ to $\leq 36$ months of age were collapsed into one group and unadjusted comparisons between it and all other groups group were carried out. Sidak correction for multiple comparisons was used; $* *=P<0.01$.

malaria-treated individuals, age was the only statistically significant factor followed by CR1, which showed a trend towards significance $(P=0.09)$. Of interest, parasite density was not important in either analysis. Lastly, in the adjusted analysis of samples from malaria-negative individuals, CD55 and IC binding capacity made the strongest contribution after age. 
a
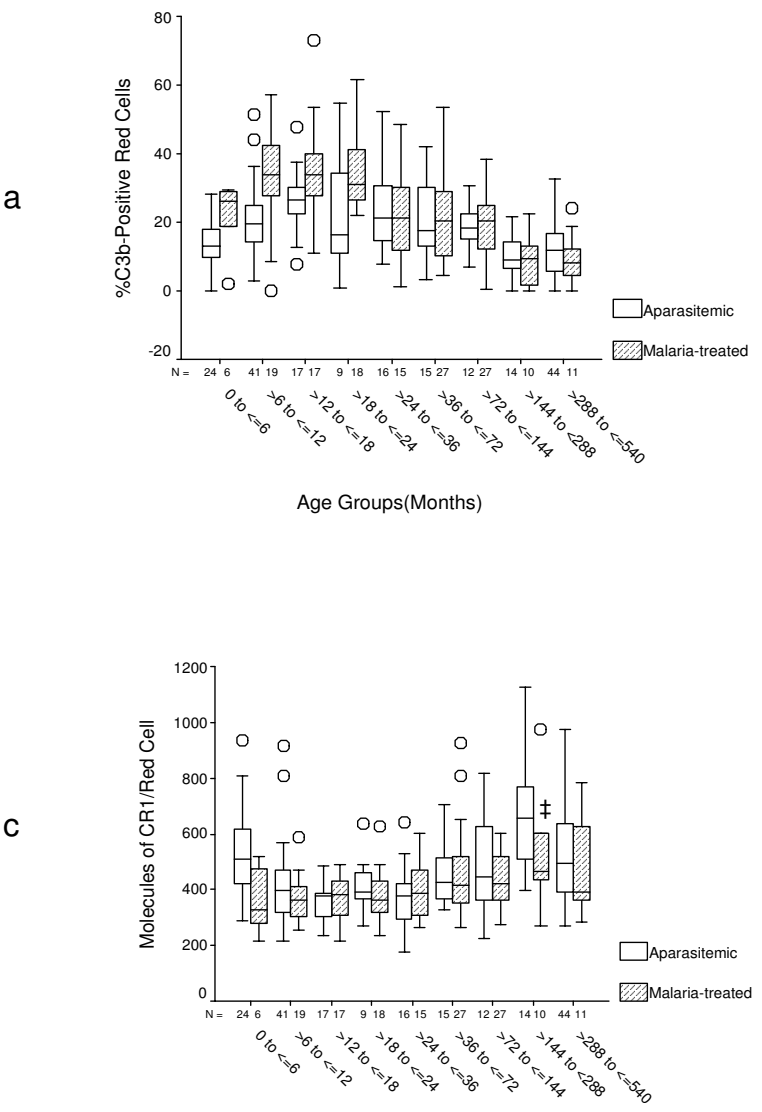

Age Groups(Months)

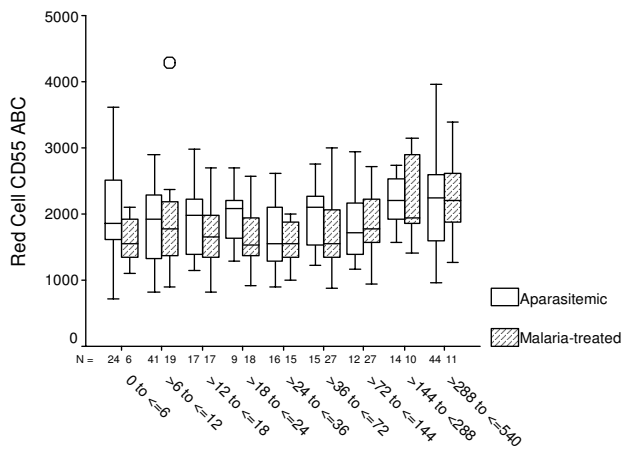

Age Groups(Months)

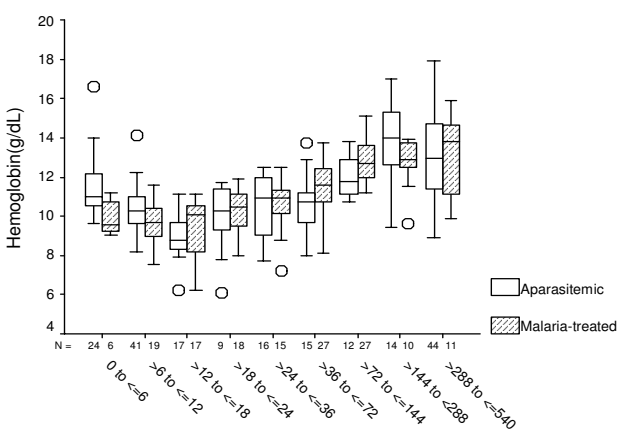

Age Groups(Months)

Figure 3

\section{Figure 3}

Changes in \%C3b-positive red cells, CRI, CD55, and hemoglobin according to malaria status. a. \%C3b-positive red cells. Unadjusted ANOVA for the difference in \%C3b-positive red cells across groups $P$ (malaria-treated) $=2.5 \times 10^{-11}$, $P($ aparasitemic $)=1.2 \times 10^{-7}$. Independent samples $t$-test for the comparison between malaria-treated and aparasitemic individuals for the indicated age groups, $* P=0.04, \uparrow P=2.8 \times 10^{-4}, \neq P=0.09, \pi P=0.03$. b. Red cell CD55. Unadjusted ANOVA for the difference in $C D 55$ across groups, $P$ (malaria-treated $)=0.01$ and $P($ aparasitemic $)=0.05$. $A B C=$ Antibody binding capacity. $c$. Red cell CRI. Unadjusted ANOVA for the difference in CRI across groups, $P$ (malaria-treated $)=0.02$ and $P$ (aparasitemic) $=1.9$ $\times 10^{-6}$. Independent samples $t$-test for the comparison between malaria-treated and aparasitemic individuals for the indicated age groups, $* P=0.0 \mathrm{I}, \uparrow P=0.58, \neq P=0.09$. $\mathrm{d}$. Hemoglobin level. Unadjusted ANOVA for the difference in Hgb level across groups, $P($ malaria-treated $)=9.8 \times 10^{-19}, P($ aparasitemic $)=3.8 \times 10^{-20}$. Independent samples $t$-test for the comparison between malaria-treated and aparasitemic individuals for the indicated age groups, $* P=0.02, \uparrow P=0.05, \neq P=0.03, \mathbb{T} P=0.1 \mathrm{I}$.

For the analysis of factors associated with the hemoglobin level (Table 4), once again age made the strongest contribution both in the unadjusted and adjusted analyses. Of all the age groups, the $>6$ to $\leq 36$ months group also had the strongest negative effect on the hemoglobin level. In the unadjusted analysis, \%C3b-positive red cells, parasite density, and red cell CR1 always exerted a significant influence on hemoglobin level. The IC binding capacity made significant contributions in the unadjusted analysis of all the samples and the samples from malaria negative individuals. In the adjusted analysis, in addition to age, red cell CR1, \%C3b-positive red cells, and CD55 made a significant contribution to the hemoglobin level using all the samples and the samples from individuals who were negative for malaria. Interestingly, CD55 among aparasitemic individuals had a negative, although very small, $\mathrm{B}$ coefficient, meaning that in this group CD55 seemed to be associated with declining hemoglobin level. For the analysis that included samples from malaria-treated individuals, red cell CR1 and age exerted the greatest influence on the hemoglobin level. 


\begin{tabular}{|c|c|c|c|c|c|c|c|c|c|c|c|}
\hline \multirow[b]{2}{*}{ Groups } & \multirow[b]{2}{*}{$\begin{array}{l}\text { Independent } \\
\text { Variables }\end{array}$} & \multicolumn{5}{|c|}{ Unadjusted } & \multicolumn{5}{|c|}{ Adjusted } \\
\hline & & $F$ & $B(\mathrm{SE})$ & $95 \% \mathrm{Cl}$ of $B$ & $\eta^{2} p$ & $P$ & $F$ & $B(\mathrm{SE})$ & $95 \% \mathrm{Cl}$ of $B$ & $\eta^{2} p$ & $P$ \\
\hline All & $\begin{array}{l}\text { Age Groups } \\
\text { (months) }\end{array}$ & 21.8 & -- & -- & 0.245 & $5.9 \times 10^{-19}$ & 11.6 & -- & -- & 0.149 & $2.5 \times 10^{-10}$ \\
\hline \multirow[t]{11}{*}{$N=342$} & 0 to $\leq 6$ & -- & $4.13(2.53)$ & -0.85 to 9.10 & 0.008 & 0.10 & -- & $3.29(2.45)$ & -1.38 to 8.29 & 0.006 & 0.18 \\
\hline & $>6$ to $\leq 36$ & -- & $15.08(1.75)$ & 11.63 to 18.53 & 0.180 & $3.1 \times 10^{-16}$ & -- & $11.61(1.81)$ & 8.05 to 15.18 & 0.111 & $1.8 \times 10^{-10}$ \\
\hline & $>36$ to $\leq 72$ & -- & $9.17(2.28)$ & 4.68 to 13.66 & 0.046 & $7.3 \times 10^{-5}$ & -- & $5.99(2.30)$ & 1.48 to 10.51 & 0.020 & 0.01 \\
\hline & $>72$ to $\leq 144$ & -- & $7.64(2.33)$ & 3.05 to 12.23 & 0.031 & $1.2 \times 10^{-3}$ & -- & $4.61(2.36)$ & -0.03 to 9.24 & 0.011 & 0.07 \\
\hline & $>144$ to $\leq 288$ & -- & $-1.64(2.72)$ & -7.00 to 3.72 & 0.001 & 0.55 & -- & $-1.38(2.68)$ & -6.64 to 3.88 & 0.001 & 0.54 \\
\hline & $>288$ to $\leq 540^{*}$ & -- & -- & -- & -- & -- & -- & -- & -- & -- & -- \\
\hline & CRI & 46.1 & $-0.026(0.004)$ & -0.034 to -0.019 & 0.119 & $5.1 \times 10^{-11}$ & 3.2 & $-0.008(0.004)$ & -0.016 to 0.001 & 0.010 & 0.07 \\
\hline & CD55 & 35.3 & $-0.007(0.001)$ & -0.009 to -0.004 & 0.094 & $7.0 \times 10^{-9}$ & 5.5 & $-0.003(0.001)$ & $-4.8 \times 10^{-3}$ to $-0.4 \times 10^{-}$ & 0.016 & 0.02 \\
\hline & Malaria Negative ${ }^{\dagger}$ & 17.8 & $-5.7(1.4)$ & -8.4 to -3.1 & 0.050 & $3.2 \times 10^{-5}$ & 6.4 & $-3.34(1.32)$ & -5.93 to -0.74 & 0.019 & 0.01 \\
\hline & Parasite Density & 8.8 & $1.9 \times 10^{-4}\left(0.6 \times 10^{-4}\right)$ & $0.6 \times 10^{-4}$ to $3.2 \times 10^{-4}$ & 0.025 & $3.2 \times 10^{-3}$ & 0.5 & $4.1 \times 10^{-5}\left(5.9 \times 10^{-5}\right)$ & $-0.8 \times 10^{-4}$ to $1.6 \times 10^{-4}$ & 0.001 & 0.49 \\
\hline & $\mathrm{ICBC}$ & 12.9 & $-0.358(0.100)$ & -0.554 to -0.162 & 0.037 & $3.8 \times 10^{-4}$ & 2.0 & $-0.130(0.092)$ & $-0.31 I$ to 0.050 & 0.006 & 0.16 \\
\hline Malaria-treated & $\begin{array}{l}\text { Age Groups } \\
\text { (months) }\end{array}$ & 12.7 & -- & -- & 0.306 & $3.2 \times 10^{-10}$ & 9.0 & -- & -- & 0.244 & $1.8 \times 10^{-7}$ \\
\hline \multirow[t]{10}{*}{$N=150$} & 0 to $\leq 6$ & -- & $12.36(6.06)$ & 0.38 to 24.35 & 0.028 & 0.04 & -- & $10.08(6.38)$ & -2.53 to 22.68 & 0.018 & 0.12 \\
\hline & $>6$ to $\leq 36$ & -- & $21.48(3.88)$ & 13.81 to 29.15 & 0.175 & $1.4 \times 10^{-7}$ & -- & $20.00(4.13)$ & 11.83 to 28.18 & 0.143 & $3.4 \times 10^{-6}$ \\
\hline & $>36$ to $\leq 72$ & -- & $10.68(4.28)$ & 2.23 to 19.13 & 0.042 & 0.01 & -- & $10.01(4.42)$ & 1.28 to 18.73 & 0.035 & 0.03 \\
\hline & $>72$ to $\leq 144$ & -- & $9.49(4.28)$ & 1.04 to 17.94 & 0.033 & 0.02 & -- & $8.25(4.43)$ & -0.51 to 17.00 & 0.024 & 0.07 \\
\hline & $>144$ to $\leq 288$ & -- & $-0.78(5.22)$ & -11.11 to 9.53 & $1.6 \times 10^{-4}$ & 0.88 & -- & $-0.69(5.26)$ & -11.10 to 9.72 & $1.2 \times 10^{-4}$ & 0.90 \\
\hline & $>288$ to $\leq 540^{*}$ & -- & -- & -- & & -- & -- & -- & -- & -- & -- \\
\hline & CRI & 13.7 & $-0.030(0.008)$ & -0.046 to -0.014 & 0.085 & $3.0 \times 10^{-4}$ & 3.0 & $-0.015(0.009)$ & -.032 to 0.002 & 0.021 & 0.09 \\
\hline & CD55 & 7.2 & $-0.005(0.002)$ & -0.009 to -0.001 & 0.047 & $7.9 \times 10^{-3}$ & 0.01 & $2.5 \times 10^{-4}\left(21.1 \times 10^{-4}\right)$ & -0.004 to 0.004 & $1.0 \times 10^{-4}$ & 0.91 \\
\hline & Parasite Density & 2.6 & $1.2 \times 10^{-4}\left(0.8 \times 10^{-4}\right)$ & $-0.3 \times 10^{-4}$ to $2.7 \times 10^{-4}$ & 0.017 & 0.11 & 0.1 & $-1.9 \times 10^{-5}\left(6.8 \times 10^{-5}\right)$ & $-1.5 \times 10^{-4}$ to $1.1 \times 10^{-4}$ & 0.001 & 0.78 \\
\hline & $\mathrm{ICBC}$ & 0.2 & $-0.069(0.17 \mathrm{I})$ & -0.408 to 0.269 & 0.001 & 0.69 & 0.3 & $0.085(0.155)$ & -0.222 to 0.392 & 0.002 & 0.59 \\
\hline Malaria Negative & $\begin{array}{l}\text { Age Groups } \\
\text { (months) }\end{array}$ & 9.9 & -- & -- & 0.210 & $2.2 \times 10^{-8}$ & 4.8 & -- & -- & 0.116 & $6.3 \times 10^{-5}$ \\
\hline \multirow[t]{9}{*}{$N=192$} & 0 to $\leq 6$ & -- & $2.07(2.50)$ & -2.87 to 7.00 & 0.004 & 0.41 & -- & $1.76(2.35)$ & -2.93 to 6.34 & 0.003 & 0.47 \\
\hline & $>6$ to $\leq 36$ & -- & $10.80(1.84)$ & 7.17 to 14.43 & 0.156 & $2.0 \times 10^{-8}$ & -- & $7.93(1.82)$ & 4.71 to 11.78 & 0.094 & $7.9 \times 10^{-6}$ \\
\hline & $>36$ to $\leq 72$ & -- & $9.23(2.95)$ & 3.41 to 15.06 & 0.050 & 0.002 & -- & $7.76(2.78)$ & 2.49 to 13.43 & 0.041 & $4.6 \times 10^{-3}$ \\
\hline & $>72$ to $\leq 144$ & -- & $7.09(3.2 \mathrm{I})$ & 0.75 to 13.43 & 0.025 & 0.03 & -- & $4.66(3.05)$ & -1.44 to 10.60 & 0.013 & 0.13 \\
\hline & $>144$ to $\leq 288$ & -- & $-1.42(3.03)$ & -7.39 to 4.56 & 0.001 & 0.64 & -- & $0.33(2.91)$ & -5.83 to 5.45 & $7.0 \times 10^{-5}$ & 0.95 \\
\hline & $>288$ to $\leq 540^{*}$ & -- & -- & -- & -- & -- & -- & -- & -- & -- & -- \\
\hline & CRI & 29.4 & $-0.022(0.004)$ & -0.030 to -0.014 & 0.134 & $1.8 \times 10^{-7}$ & 1.0 & $-0.004(0.005)$ & -0.014 to 0.005 & 0.005 & 0.33 \\
\hline & CD55 & 27.0 & $-0.006(0.001)$ & -0.009 to -0.004 & 0.124 & $5.2 \times 10^{-7}$ & 8.6 & $-0.004(0.001)$ & -0.006 to -0.001 & 0.045 & $3.8 \times 10^{-3}$ \\
\hline & ICBC & 26.9 & $-0.564(0.109)$ & -0.779 to -0.350 & 0.124 & $5.4 \times 10^{-7}$ & 9.0 & $-0.326(0.109)$ & -0.540 to -0.111 & 0.047 & $3.1 \times 10^{-3}$ \\
\hline
\end{tabular}

* $B$ for this group set to ' $O$ ' as reference.

政 0 ' as reference.

. 


\begin{tabular}{|c|c|c|c|c|c|c|c|c|c|c|c|}
\hline \multirow[b]{2}{*}{ Groups } & \multirow[b]{2}{*}{$\begin{array}{l}\text { Independent } \\
\text { Variables }\end{array}$} & \multicolumn{5}{|c|}{ Unadjusted } & \multicolumn{5}{|c|}{ Adjusted } \\
\hline & & $F$ & $B(\mathrm{SE})$ & $95 \% \mathrm{Cl}$ of $B$ & $\eta^{2} p$ & $P$ & $F$ & $B(\mathrm{SE})$ & $95 \% C l$ of $B$ & $\eta^{2} p$ & $P$ \\
\hline All & $\begin{array}{l}\text { Age Groups } \\
\text { (months) }\end{array}$ & 48.5 & -- & -- & 0.419 & $9.6 \times 10^{-38}$ & 26.5 & -- & -- & 0.287 & $1.5 \times 10^{-22}$ \\
\hline \multirow[t]{12}{*}{$N=342$} & 0 to $\leq 6$ & -- & $-1.94(0.36)$ & -2.64 to -1.23 & 0.080 & $1.2 \times 10^{-7}$ & -- & $-1.86(0.34)$ & -2.54 to -1.18 & 0.080 & $1.5 \times 10^{-7}$ \\
\hline & $>6$ to $\leq 36$ & -- & $-3.13(0.25)$ & -3.62 to -2.64 & 0.321 & $4.7 \times 10^{-30}$ & -- & $-2.59(0.27)$ & -3.13 to -2.07 & 0.219 & $7.3 \times 10^{-19}$ \\
\hline & $>36$ to $\leq 72$ & -- & $-1.94(0.32)$ & -2.58 to -1.31 & 0.097 & $5.0 \times 10^{-9}$ & -- & $-1.72(0.33)$ & -2.36 to -1.08 & 0.078 & $2.3 \times 10^{-7}$ \\
\hline & $>72$ to $\leq 144$ & -- & $-0.54(0.33)$ & -1.19 to 0.11 & 0.008 & 0.10 & -- & $-0.35(0.33)$ & -1.01 to 0.30 & 0.003 & 0.29 \\
\hline & $>144$ to $\leq 288$ & -- & $0.20(0.39)$ & -0.55 to 0.96 & 0.001 & 0.60 & -- & $-0.11(0.38)$ & -0.85 to 0.63 & $2.6 \times 10^{-4}$ & 0.77 \\
\hline & $>288$ to $\leq 540^{*}$ & -- & -- & -- & -- & -- & -- & -- & -- & -- & -- \\
\hline & CRI & 63.3 & $0.005(0.001)$ & 0.004 to 0.006 & 0.157 & $2.7 \times 10^{-14}$ & 20.4 & $0.003(0.001)$ & 0.002 to 0.004 & 0.058 & $8.7 \times 10^{-6}$ \\
\hline & CD55 & 10.3 & $5.9 \times 10^{-4}\left(1.8 \times 10^{-4}\right)$ & $2.3 \times 10^{-4}$ to $9.5 \times 10^{-4}$ & 0.029 & $1.5 \times 10^{-3}$ & 5.9 & $-3.8 \times 10^{-4}\left(1.6 \times 10^{-4}\right)$ & $-6.9 \times 10^{-4}$ to $-0.7 \times 10^{-4}$ & 0.018 & 0.02 \\
\hline & Malaria Status ${ }^{\dagger}$ & 1.2 & $0.246(0.224)$ & -0.195 to 0.686 & 0.004 & 0.27 & 0.3 & $-0.103(0.187)$ & -0.471 to 0.265 & 0.001 & 0.58 \\
\hline & Parasite Density & 4.9 & $-2.3 \times 10^{-5}\left(1.0 \times 10^{-5}\right)$ & $-4.3 \times 10^{-5}$ to $-0.3 \times 10^{-5}$ & 0.014 & 0.03 & $1.1 \times 10^{-5}$ & $0.3 \times 10^{-7}\left(82.7 \times 10^{-7}\right)$ & $-1.6 \times 10^{-5}$ to $1.6 \times 10^{-5}$ & $3.5 \times 10^{-8}$ & 1.00 \\
\hline & ICBC & 11.9 & $0.056(0.016)$ & 0.024 to 0.087 & 0.034 & $6.3 \times 10^{-4}$ & 0.02 & $0.002(0.013)$ & -0.024 to 0.027 & $6.0 \times 10^{-5}$ & 0.89 \\
\hline & $\begin{array}{l}\text { \%C3b-positive } \\
\text { Red Cells }\end{array}$ & 77.6 & $-0.070(0.008)$ & -0.085 to -0.054 & 0.186 & $6.6 \times 10^{-17}$ & 10.5 & $-0.025(0.008)$ & -0.040 to -0.010 & 0.031 & $1.3 \times 10^{-3}$ \\
\hline Malaria-treated & $\begin{array}{l}\text { Age Groups } \\
\text { (months) }\end{array}$ & 27.2 & -- & -- & 0.486 & $2.7 \times 10^{-19}$ & 15.3 & -- & -- & 0.355 & $6.0 \times 10^{-12}$ \\
\hline \multirow[t]{11}{*}{$N=150$} & 0 to $\leq 6$ & -- & $-3.09(0.68)$ & -4.42 to -1.75 & 0.127 & $1.1 \times 10^{-5}$ & -- & $-2.74(0.68)$ & -4.09 to -1.39 & 0.103 & $1.0 \times 10^{-4}$ \\
\hline & $>6$ to $\leq 36$ & -- & $-2.98(0.43)$ & -3.83 to -2.12 & 0.247 & $1.7 \times 10^{-10}$ & -- & $-2.54(0.48)$ & -3.48 to -1.60 & 0.170 & $3.7 \times 10^{-7}$ \\
\hline & $>36$ to $\leq 72$ & -- & $-1.53(0.48)$ & -2.47 to -0.59 & 0.067 & $1.7 \times 10^{-3}$ & -- & $-1.45(0.48)$ & -2.39 to -0.50 & 0.062 & $2.9 \times 10^{-3}$ \\
\hline & $>72$ to $\leq 144$ & -- & $-0.12(0.48)$ & -1.06 to 0.82 & $4.5 \times 10^{-4}$ & 0.80 & -- & $-0.03(0.48)$ & -0.91 to 0.97 & $3.0 \times 10^{-5}$ & 0.95 \\
\hline & $>144$ to $\leq 288$ & -- & $-0.31(0.58)$ & -1.46 to 0.85 & 0.002 & 0.60 & -- & $-0.46(0.56)$ & -1.56 to 0.65 & 0.005 & 0.41 \\
\hline & $>288$ to $\leq 540^{*}$ & -- & -- & -- & & -- & -- & -- & -- & -- & -- \\
\hline & CRI & 28.2 & $0.005(0.001)$ & 0.003 to 0.007 & 0.160 & $3.9 \times 10^{-7}$ & 13.0 & $0.003(0.001)$ & 0.002 to 0.005 & 0.085 & $4.4 \times 10^{-4}$ \\
\hline & CD55 & 7.2 & $7.0 \times 10^{-4}\left(2.6 \times 10^{-4}\right)$ & $1.9 \times 10^{-4}$ to $12.2 \times 10^{-4}$ & 0.047 & $8.1 \times 10^{-3}$ & 2.0 & $-3.2 \times 10^{-4}\left(2.2 \times 10^{-4}\right)$ & $-7.6 \times 10^{-4}$ to $1.3 \times 10^{-4}$ & 0.014 & 0.16 \\
\hline & Parasite Density & 5.0 & $-2.2 \times 10^{-5}\left(1.0 \times 10^{-5}\right)$ & $-4.1 \times 10^{-5}$ to $-0.3 \times 10^{-5}$ & 0.033 & 0.03 & 0.002 & $3.2 \times 10^{-7}\left(0.7 \times 10^{-7}\right)$ & $-1.4 \times 10^{-5}$ to $1.5 \times 10^{-5}$ & $1.4 \times 10^{-5}$ & 0.96 \\
\hline & ICBC & 3.2 & $0.039(0.022)$ & 0.004 to 0.083 & 0.021 & 0.08 & 0.3 & $0.008(0.017)$ & -0.024 to 0.04 I & 0.002 & 0.61 \\
\hline & $\begin{array}{l}\text { \%C3b-positive } \\
\text { Red Cells }\end{array}$ & 34.9 & $-0.057(0.010)$ & -0.075 to -0.038 & 0.191 & $2.3 \times 10^{-8}$ & 1.9 & $-0.012(0.009)$ & -0.030 to 0.005 & 0.014 & 0.17 \\
\hline $\begin{array}{l}\text { Malaria } \\
\text { Negative }\end{array}$ & $\begin{array}{l}\text { Age Groups } \\
\text { (months) }\end{array}$ & 26.4 & -- & -- & 0.415 & $4.4 \times 10^{-20}$ & 14.4 & -- & -- & 0.284 & $7.0 \times 10^{-12}$ \\
\hline \multirow[t]{10}{*}{$N=192$} & 0 to $\leq 6$ & -- & $-1.65(0.44)$ & -2.51 to -0.79 & 0.072 & $2.1 \times 10^{-4}$ & -- & $-1.63(0.42)$ & -2.46 to -0.80 & 0.077 & $1.4 \times 10^{-4}$ \\
\hline & $>6$ to $\leq 36$ & -- & $-3.15(0.32)$ & -3.78 to -2.52 & 0.342 & $1.2 \times 10^{-18}$ & -- & $-2.62(0.34)$ & -3.30 to -1.95 & 0.246 & $8.0 \times 10^{-13}$ \\
\hline & $>36$ to $\leq 72$ & -- & $-2.4 I(0.5 I)$ & -3.43 to -1.40 & 0.106 & $5.2 \times 10^{-6}$ & -- & $-1.97(0.5 \mathrm{I})$ & -2.97 to -0.97 & 0.077 & $1.4 \times 10^{-4}$ \\
\hline & $>72$ to $\leq 144$ & -- & $-1.15(0.56)$ & -2.25 to -0.04 & 0.022 & 0.04 & -- & $-0.98(0.55)$ & -2.06 to 0.10 & 0.017 & 0.07 \\
\hline & $>144$ to $\leq 288$ & -- & $0.65(0.53)$ & -0.39 to 1.69 & 0.008 & 0.22 & .- & $0.31(0.52)$ & -0.71 to 1.33 & 0.002 & 0.55 \\
\hline & $>288$ to $\leq 540 *$ & -- & -- & -- & -- & -- & -- & -- & -- & -- & -- \\
\hline & CRI & 33.9 & $0.005(0.001)$ & 0.003 to 0.006 & 0.151 & $2.4 \times 10^{-8}$ & 7.6 & $0.002(0.001)$ & 0.001 to 0.004 & 0.040 & 0.01 \\
\hline & CD55 & 3.5 & $4.9 \times 10^{-4}\left(2.6 \times 10^{-4}\right)$ & 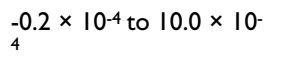 & 0.018 & 0.06 & 5.0 & $-4.9 \times 10^{-4}\left(2.2 \times 10^{-4}\right)$ & $-9.3 \times 10^{-4}$ to $-0.6 \times 10^{-4}$ & 0.027 & 0.03 \\
\hline & ICBC & 8.6 & $0.068(0.023)$ & 0.022 to 0.113 & 0.043 & $3.7 \times 10^{-3}$ & 0.4 & $-0.012(0.020)$ & -0.052 to 0.027 & 0.002 & 0.53 \\
\hline & $\begin{array}{l}\text { \%C3b-positive } \\
\text { Red Cells }\end{array}$ & 46.3 & $-0.090(0.013)$ & -0.116 to -0.064 & 0.196 & $1.3 \times 10^{-10}$ & 10.7 & $-0.043(0.013)$ & -0.069 to -0.017 & 0.056 & $1.3 \times 10^{-3}$ \\
\hline
\end{tabular}




\section{Discussion}

Severe anemia due to $P$. falciparum occurs principally in young children and is most common in areas of intense malaria transmission $[4,5,38]$. Cerebral malaria, on the other hand, occurs in older children and adults in areas of low transmission, and the incidence can increase with age [5,39]. Identifying the mechanisms underlying these disparities in age-related susceptibilities is critical to understanding the pathogenesis of severe malaria. We previously reported that the levels of red cell complement regulatory proteins CR1 and CD55, which protect red cells from autologous complement attack, vary with age, being high in neonates, decreasing after 6 months and increasing some time after into adulthood [40]. This pattern of expression is independent of malaria infection and of the ethnic background of the population [41]. Our primary objective was to determine whether low levels of red cell complement regulatory proteins are associated with increased C3b deposition on red cells and, secondarily, with low hemoglobin in a malaria-endemic area. Because we have previously observed that individuals with malaria have lower levels of red cell complement regulatory proteins $[13,42]$, we controlled for the effect of parasitemia on this parameter by administering anti-malarial treatment to malaria-positive participants and collecting the blood sample only when they were smear negative. Restrictions on the amount of blood that can be drawn from very young children limited the number of blood draws within our time frame to one.

The relationship between red cell C3b and red cell complement regulatory protein expression seemed complex (Figures 1 and 2a). Red cell CR1 appeared to be more agedependent than CD55 or the IC binding capacity. The peak of \%C3b-positive red cells coincided with the nadir of red cell CR1 (Figures 1b and 2a) suggesting a stronger relationship between $\mathrm{C} 3 \mathrm{~b}$ and CR1 than between C3b and CD55 or the IC binding capacity. However, in the overall ANOVA model (Table 3) CD55 made a stronger contribution. This could be explained by the fact that CD55 seemed to be more important in preventing C3b deposition in malaria-negative individuals, who were more numerous in the study group. Although not statistically significant $(P=0.09), \mathrm{CR} 1$ appeared to be more important than CD55 in protecting red cells from C3b deposition during malaria infection (Table 3). These observations point to distinct mechanisms of action between CR1 and CD55. Since studies have shown that there is active complement activation during malaria infection $[9,43]$, our observations suggest that CR1 is more effective than CD55 at preventing C3b deposition on cells.

The presence of parasitemia seemed to be a more important contributor to $\mathrm{C} 3 \mathrm{~b}$ deposition than the degree of par- asitemia. This is somewhat surprising since although parasite density peaked at an earlier age than parasite prevalence (Figures $2 \mathrm{~b}$ and $2 \mathrm{c}$ ), both parameters peaked within the same age range as the peak for \%C3b-positive red cells (Figure 2a). However, malaria-treated individuals $\leq 24$ months of age tended to have higher \%C3b-positive red cells than malaria-negative individuals, regardless of the level of parasitemia (Figures $2 \mathrm{c}$ and $3 \mathrm{a}$ ), suggesting that the level of parasitemia is less important. Although we cannot exclude the possibility that malaria treatment may have exacerbated C3b deposition on red cells, and thus biased our results, we have observed C3b deposition on red cells of acutely infected children prior to treatment in other studies [44]. Thus, the C3b deposition on red cells of children who were treated for malaria is likely residual from the original infection.

It is interesting that increased C3b deposition was also seen on red cells of children with low red cell complement regulatory protein but without malaria infection, suggesting that there is a defect in the normal regulatory mechanisms during this age that prevent spontaneous complement activation. Alternatively, $\mathrm{C} 3 \mathrm{~b}$ on aparasitemic individuals may have been residual from recent previous malaria infections or infections with other agents. It is also possible that some or many of these individuals have levels of parasitemia below the limit of detection of microscopy.

The question of whether parasite prevalence or parasite density is a contributor to uninfected red cell destruction has important ramifications for the understanding of the pathogenesis of severe anemia during malaria. Current belief is that natural acquired immunity does not sterilize but suppresses the level of parasitemia and, therefore, parasite density is a reflection of the level of immunity [45]. Hence, if malaria prevalence is a function of exposure only, with no role for acquired immunity, at least early on, this would suggest that the age specificity of severe anemia due to malaria is being driven solely by the physiologic changes in the ability of children to regulate complement activation, namely age-related declines in red cell complement regulators. In this case, one would predict that there would be no relationship between severe anemia and the level of parasitemia, as we have found in previous studies $[13,46,47]$. On the other hand, if changes in parasite prevalence are being driven by acquisition and loss of immunity then obviously immunity would play a role, but in this case one would expect parasite density to be an important factor as well.

The most important variables that influenced the hemoglobin level in this study were age, red cell CR1, \%C3bpositive red cells, and red cell CD55 (Table 4). Interestingly, the effect of CD55 on hemoglobin was always neg- 
ative. The most likely reason is because as CD55 decreased to a nadir at age $>24$ to $\leq 36$ months the hemoglobin increased (Figures $2 \mathrm{a}$ and $2 \mathrm{c}$ ). These observations are consistent with the role of $\mathrm{C} 3 \mathrm{~b}$ in the destruction of red cells and with the more important role of CR1 over CD55 in the protection of red cells from complement activation. In the analysis of samples from malaria-treated individuals, only CR1 and age made significant contributions. The absence of \%C3b as an important factor here is surprising given the high proportion of C3b-positive red cells associated with low hemoglobin in malaria-treated individuals (Figures $3 \mathrm{a}$ and 3d), and suggests that even in the setting of high C3b deposition high red cell CR1 may be protective. The failure of parasite density and malaria status to make significant contributions to the hemoglobin level probably reflects the fact that malaria treatment eliminated any difference in the hemoglobin level between malaria-treated and aparasitemic participants (data not shown). Therefore, the model presented here is free of the direct effects of the parasite on the destruction of red cells but retains the indirect effects of complement-mediated mechanisms.

The two ANOVA models (Tables 3 and 4) suggest the importance of age as the strongest factor determining $\mathrm{C} 3 \mathrm{~b}$ deposition on red cells and the hemoglobin level. The implication of this finding for complement activation is that quite possibly there still remain to be identified other age-related factors that regulate complement activation and deposition on red cells. The relationship between age and hemoglobin level is probably multifactorial and likely includes factors such as diet, and iron deficiency as well as the contribution of age effects on complement regulation.

Our data suggest that children $>6$ to $\leq 36$ months of age who develop malaria are at high risk of uninfected red cell destruction due to ineffective complement regulation. They have relatively low red cell CR1 that may be insufficient to control complement activation on cell surfaces. On the other side of this equation is the contribution of macrophage activation, which should also be considered. Macrophages can be activated by the malaria pigment hemozoin as well as by malaria GPI, leading to increased production of pro-inflammatory cytokines which can upregulate the expression of complement receptors leading to phagocytosis [48-50]. In addition, several studies have documented an inverse relationship between TNF- $\alpha$ production, in response to malaria infection, and age $[51,52]$. Thus, in addition to high red cell C3b, parasitemic children $\leq 24$ months of age may have overstimulated macrophages, making their red cells more susceptible to erythrophagocytosis and severe anemia.

\section{Conclusion}

These results suggest that increasing malaria prevalence among children $>6$ to $\leq 36$ months of age in western Kenya together with low red cell CR1 and CD55 levels result in increased $\mathrm{C} 3 \mathrm{~b}$ deposition on red cells leading to increased red cell destruction by phagocytosis. The strong contribution of age to $\mathrm{C} 3 \mathrm{~b}$ deposition suggests that there are still additional unidentified age-related factors that increase the susceptibility to $\mathrm{C} 3 \mathrm{~b}$ deposition on red cells and red cell destruction.

\section{Abbreviations}

ANCOVA: analysis of covariance; ANOVA: analysis of variance; DAF: decay accelerating factor; EDTA: ethylenediaminetetraacetic acid; FITC: fluorescein isothiocyanate; GPI: glycosyl-phosphatidyl-inositol; IC: immune complex; MFI: median fluorescence intensity; PBS: phosphate buffered saline.

\section{Competing interests}

The authors declare that they have no competing interests.

\section{Authors' contributions}

COO carried out flow cytometry to measure the red cell $\mathrm{C} 3 \mathrm{~b}$. WO supervised the recruitment and evaluation of the study participants. CA supervised the measurement of clinical laboratory parameters. MMO carried out flow cytometry to measure red cell CR1, CD55, and IC binding capacity. JAS and WO designed the study and wrote the protocol. COO and JAS drafted the manuscript which was reviewed and approved by all.

\section{Acknowledgements}

We would like to thank the participants for their willingness to contribute to this research endeavor. We are indebted to our dedicated staff of clinicians, nurses, drivers and field workers who made this study possible. In particular, we thank Stacey Gondi for serving as research coordinator. Mr. Meng Shi is thanked for statistical advice. This work is published with the permission of the Office of the Director, the Kenya Medical Research Institute.

This work was supported in part by the US Army Medical Research and Materiel Command and by a grant from the National Heart Lung and Blood Institute (ROI HL 7502), José A. Stoute PI. Walter Otieno was supported by a training grant from the Fogarty International Center (I D43 TW06239).

"The views of the authors do not purport to reflect the position of the Department of the Army or the Department of Defense. The U.S. Government has the right to retain a nonexclusive, royalty-free license in and to any copyright covering this paper."

\section{References}

I. Breman JG: The ears of the hippopotamus: manifestations, determinants, and estimates of the malaria burden. Am J Trop Med Hyg 200I, 64: I-II.

2. Snow RW, Bastos dAI, Lowe BS, Kabiru EW, Nevill CG, Mwankusye S, Kassiga G, Marsh K, Teuscher T: Severe childhood malaria in 
two areas of markedly different falciparum transmission in east Africa. Acta Trop 1994, 57:289-300.

3. Imbert P, Sartelet I, Rogier C, Ka S, Baujat G, Candito D: Severe malaria among children in a low seasonal transmission area, Dakar, Senegal: influence of age on clinical presentation. Trans R Soc Trop Med Hyg 1997, 9 I:22-24.

4. Modiano D, Sirima BS, Sawadogo A, Sanou I, Pare J, Konate A, Pagnon $\mathrm{F}$ : Severe malaria in Burkina Faso: influence of age and transmission level on clinical presentation. Am J Trop Med Hyg 1998, 59:539-542.

5. Marsh K, Snow RW: Malaria transmission and morbidity. Parassitologia 1999, 41:241-246.

6. Looareesuwan S, Ho M, Wattanagoon Y, White NJ, Warrell DA, Bunnag $D$, Harinasuta $T$, Wyler $D$ J: Dynamic alteration in splenic function during acute falciparum malaria. N Engl J Med I987, 317:675-679.

7. Camacho LH, Gordeuk VR, Wilairatana P, Pootrakul P, Brittenham GM, Looareesuwan S: The course of anaemia after the treatment of acute, falciparum malaria. Ann Trop Med Parasitol 1998, 92:525-537.

8. Jakeman GN, Saul A, Hogarth WL, Collins WE: Anaemia of acute malaria infections in non-immune patients primarily results from destruction of uninfected erythrocytes. Parasitology 1999 I I9(Pt 2): 127-I33.

9. Jhaveri KN, Ghosh K, Mohanty D, Parmar BD, Surati RR, Camoens HM, Joshi SH, lyer YS, Desai A, Badakere SS: Autoantibodies, immunoglobulins, complement and circulating immune complexes in acute malaria. Natl Med J India 1997, I0:5-7.

10. Roestenberg M, McCall M, Mollnes TE, van DM, Sprong T, Klasen I, Hermsen CC, Sauerwein RW, van dV: Complement activation in experimental human malaria infection. Trans $R$ Soc Trop Med Hyg 2007, 10 I:643-649.

II. Freedman J: Membrane-bound immunoglobulins and complement components on young and old red cells. Transfusion 1984, 24:477-48I.

12. Goka BQ, Kwarko H, Kurtzhals JA, Gyan B, Ofori-Adjei E, Ohene SA, Hviid L, Akanmori BD, Neequaye J: Complement binding to erythrocytes is associated with macrophage activation and reduced haemoglobin in Plasmodium falciparum malaria. Trans $R$ Soc Trop Med Hyg 200I, 95:545-549.

13. Waitumbi JN, Opollo MO, Muga RO, Misore AO, Stoute JA: Red cell surface changes and erythrophagocytosis in children with severe Plasmodium falciparum anemia. Blood 2000, 95: $|48|-\mid 486$

14. Weiss L, Fischer E, Haeffner-Cavaillon N, Jouvin MH, Appay MD, Bariety J, Kazatchkine M: The human C3b receptor (CRI). Adv Nephrol Necker Hosp 1989, 18:249-269.

15. Yazdanbakhsh K: Review: complement receptor I therapeutics for prevention of immune hemolysis. Immunohematology 2005, 2I(3): $109-118$.

16. Madi N, Paccaud JP, Steiger G, Schifferli JA: Immune complex binding efficiency of erythrocyte complement receptor I (CRI). Clin Exp Immunol I99I, 84:9-I5.

17. Reinagel ML, Gezen M, Ferguson PJ, Kuhn S, Martin EN, Taylor RP: The primate erythrocyte complement receptor (CRI) as a privileged site: binding of immunoglobulin $\mathbf{G}$ to erythrocyte CRI does not target erythrocytes for phagocytosis. Blood 1997, 89: 1068-1077.

18. Nicholson-Weller A: Decay accelerating factor (CD55). Curr Top Microbiol Immunol 1992, I 78:7-30.

19. Miwa T, Song WC: Membrane complement regulatory proteins: insight from animal studies and relevance to human diseases. Int Immunopharmacol 200 I, I:445-459.

20. Parker C]: Regulation of complement by membrane proteins: an overview. Curr Top Microbiol Immunol 1992, 178: I-6.

21. Mibei EK, Orago AS, Stoute JA: Immune complex levels in children with severe Plasmodium falciparum malaria. Am J Trop Med Hyg 2005, 72:593-599.

22. Owuor BO, Odhiambo CO, Otieno WO, Adhiambo C, Makawiti DW Stoute JA: Reduced immune complex binding capacity and increased complement susceptibility of red cells from children with severe malaria-associated anemia. Mol Med 2008, 14:89-97.

23. Waitumbi JN, Donvito B, Kisserli A, Cohen JH, Stoute JA: Agerelated changes in red blood cell complement regulatory proteins and susceptibility to severe malaria. I Infect Dis 2004 190: I|83-II9|.

24. Stoute JA: Complement-regulatory proteins in severe malaria: too little or too much of a good thing? Trends Parasitol 2005, $21: 218-223$

25. Beier JC, Perkins PV, Onyango FK, Gargan TP, Oster CN, Whitmire RE, Koech DK, Roberts CR: Characterization of malaria transmission by Anopheles (Diptera: Culicidae) in western Kenya in preparation for malaria vaccine trials. J Med Entomol 1990, 27:570-577.

26. Mibei EK, Orago AS, Stoute JA: Immune complex levels in children with severe Plasmodium falciparum malaria. Am J Trop Med Hyg 2005, 72:593-599.

27. Waitumbi JN, Donvito B, Kisserli A, Cohen JH, Stoute JA: Agerelated changes in red blood cell complement regulatory proteins and susceptibility to severe malaria. J Infect Dis 2004, 190: II83-1191.

28. Waitumbi JN, Donvito B, Kisserli A, Cohen JH, Stoute JA: Agerelated changes in red blood cell complement regulatory proteins and susceptibility to severe malaria. J Infect Dis 2004, 190: II83-II91.

29. Pascual M, Danielsson C, Steiger G, Schifferli JA: Proteolytic cleavage of CRI on human erythrocytes in vivo: evidence for enhanced cleavage in AIDS. Eur J Immunol 1994, 24:702-708.

30. Takemura S, Deguchi M, Ueda M, Yoshida N, Kato H, Yoshikawa T, Sugino $S$, Kondo M: C3b receptor (CRI) on erythrocytes in various diseases. Immunol Lett 1984, 7:325-328.

31. Ross GD, Yount WJ, Walport MJ, Winfield JB, Parker CJ, Fuller CR, Taylor RP, Myones BL, Lachmann PJ: Disease-associated loss of erythrocyte complement receptors (CRI, C3b receptors) in patients with systemic lupus erythematosus and other diseases involving autoantibodies and/or complement activation. J Immunol 1985, 135:2005-20I4.

32. Kokwaro G, Mwai L, Nzila A: Artemether/lumefantrine in the treatment of uncomplicated falciparum malaria. Expert Opin Pharmacother 2007, 8:75-94.

33. Cockburn IA, Donvito B, Cohen JH, Rowe JA: A simple method for accurate quantification of complement receptor $I$ on erythrocytes preserved by fixing or freezing. J Immunol Methods 2002, 27I:59-64.

34. Waitumbi JN, Donvito B, Kisserli A, Cohen JH, Stoute JA: Agerelated changes in red blood cell complement regulatory proteins and susceptibility to severe malaria. J Infect Dis 2004, 190:1183-1191.

35. Schwartz A, Ottinger J, Wallace E, Poon R, Fernandez-Repollet E: Quantitative determination of antibody binding capacity (ABC) by flow cytometry. Eur J Histochem 1994, 38(Suppl I): $13-20$

36. Overton WR: Modified histogram subtraction technique for analysis of flow cytometry data. Cytometry 1988, 9:619-626.

37. Waitumbi JN, Donvito B, Kisserli A, Cohen JH, Stoute JA: Agerelated changes in red blood cell complement regulatory proteins and susceptibility to severe malaria. J Infect Dis 2004 , 190: II83-1191.

38. Snow RW, Omumbo JA, Lowe B, Molyneux CS, Obiero JO, Palmer A, Weber MW, Pinder M, Nahlen B, Obonyo C, Newbold C, Gupta $S$, Marsh K: Relation between severe malaria morbidity in children and level of Plasmodium falciparum transmission in Africa. Lancet 1997, 349:1650-1654.

39. Luxemburger C, Ricci F, Nosten F, Raimond D, Bathet S, White NJ: The epidemiology of severe malaria in an area of low transmission in Thailand. Trans R Soc Trop Med Hyg 1997, 91:256-262.

40. Waitumbi JN, Donvito B, Kisserli A, Cohen JH, Stoute JA: Agerelated changes in red blood cell complement regulatory proteins and susceptibility to severe malaria. J Infect Dis 2004, 190:1183-1191.

4I. Waitumbi JN, Donvito B, Kisserli A, Cohen JH, Stoute JA: Agerelated changes in red blood cell complement regulatory proteins and susceptibility to severe malaria. J Infect Dis 2004, 190: II83-1191.

42. Waitumbi JN, Donvito B, Kisserli A, Cohen JH, Stoute JA: Agerelated changes in red blood cell complement regulatory proteins and susceptibility to severe malaria. J Infect Dis 2004, 190:1183-1191.

43. Roestenberg M, McCall M, Mollnes TE, van DM, Sprong T, Klasen I, Hermsen CC, Sauerwein RW, van dV: Complement activation in 
experimental human malaria infection. Trans $R$ Soc Trop Med Hyg 2007, 101:643-649.

44. Owuor BO, Odhiambo CO, Otieno WO, Adhiambo C, Makawiti DW, Stoute JA: Reduced immune complex binding capacity and increased complement susceptibility of red cells from children with severe malaria-associated anemia. Mol Med 2008, I 4:89-97.

45. Rogier C, Tall A, Diagne N, Fontenille D, Spiegel A, Trape JF: Plasmodium falciparum clinical malaria: lessons from longitudinal studies in Senegal. Parassitologia 1999, 4I:255-259.

46. Owuor BO, Odhiambo CO, Otieno WO, Adhiambo C, Makawiti DW, Stoute JA: Reduced immune complex binding capacity and increased complement susceptibility of red cells from children with severe malaria-associated anemia. Mol Med 2008, I 4:89-97.

47. Waitumbi JN, Donvito B, Kisserli A, Cohen JH, Stoute JA: Agerelated changes in red blood cell complement regulatory proteins and susceptibility to severe malaria. J Infect Dis 2004 , 190: II83-1191.

48. Jaramillo M, Godbout M, Olivier M: Hemozoin induces macrophage chemokine expression through oxidative stressdependent and -independent mechanisms. J Immunol 2005, I 74:475-484.

49. Krishnegowda G, Hajjar AM, Zhu J, Douglass EJ, Uematsu S, Akira S, Woods AS, Gowda DC: Induction of proinflammatory responses in macrophages by the glycosylphosphatidylinositols of Plasmodium falciparum: cell signaling receptors, glycosylphosphatidylinositol (GPI) structural requirement, and regulation of GPI activity. J Biol Chem 2005, 280:8606-86I6.

50. Kitagawa S, Yuo A, Yagisawa M, Azuma E, Yoshida M, Furukawa Y, Takahashi M, Masuyama J, Takaku F: Activation of human monocyte functions by tumor necrosis factor: rapid priming for enhanced release of superoxide and erythrophagocytosis, but no direct triggering of superoxide release. Exp Hematol 1996, 24:559-567.

51. Mshana RN, Boulandi J, Mshana NM, Mayombo J, Mendome G: Cytokines in the pathogenesis of malaria: levels of IL-I beta IL-4, IL- 6, TNF-alpha and IFN-gamma in plasma of healthy individuals and malaria patients in a holoendemic area. I Clin Lab Immunol |99|, 34:|31-139.

52. Nyakundi JN, Warn P, Newton C, Mumo J, Jephthah-Ochola J: Serum tumour necrosis factor in children suffering from Plasmodium falciparum infection in Kilifi District, Kenya. Trans R Soc Trop Med Hyg 1994, 88:667-670.

\section{Pre-publication history}

The pre-publication history for this paper can be accessed here:

http://www.biomedcentral.com/1741-7015/6/23/prepub
Publish with Bio Med Central and every scientist can read your work free of charge

"BioMed Central will be the most significant development for disseminating the results of biomedical research in our lifetime. "

Sir Paul Nurse, Cancer Research UK

Your research papers will be:

- available free of charge to the entire biomedical community

- peer reviewed and published immediately upon acceptance

- cited in PubMed and archived on PubMed Central

- yours - you keep the copyright
BioMedcentral 